\title{
SEDENTARY BEHAVIOR AND NUTRITIONAL STATUS AMONG OLDER ADULTS: A META-ANALYSIS
}

\author{
COMPORTAMENTO SEDENTÁRIO E ESTADO NUTRICIONAL DE IDOSOS: UMAMETANÁLISE
}

COMPORTAMIENTO SEDENTARIO Y EL ESTADO NUTRICIONAL DE LOS ANCIANOS: UNAMETA-ANÁLISIS

Bruno de Freitas Camilo' (Physical Education Professional)

Talita Inácio Martins Resende ${ }^{1}$ (Physical Education Professional) Édimo Fernando Alves Moreira ${ }^{2}$ (Professional of Statistics)

Renata Damião

(Nutritionist)

\section{Universidade Federal do} Triângulo Mineiro (UFTM), Department of Post-Graduation in Physical Education, Nucleus of Studies in Physical Activity and Health, Uberaba, MG, Brazil. 2. Instituto Federal do Triângulo Mineiro (IFTM), Uberaba, MG, Brazil.

\section{Correspondence:}

Programa de Pós-Graduação em Educação Física da Universidade Federal do Triângulo Mineiro (UFTM), Nucleus of Studies in Physical Activity and Health. Av. Tutunas, 490, Tutunas, Uberaba, MG, Brazil. 38061-500. brunodefreitascamilo@yahoo.com.br

\begin{abstract}
The accelerated modernization process has entailed changes in the lifestyle of people, such as exposure to sedentary behavior, and this in turn may affect the nutritional status. The aim of this systematic review with meta-analysis was to analyze observational studies that assessed the association between exposure time to sedentary behavior and nutritional status (overweight/malnutrition) in individuals aged $\geq 60$ years. BVS, PubMed and Web of Science were the databases used in the search for observational studies, published until November 28, 2017, which have examined the association between exposure time to sedentary behavior and nutritional status. Two authors undertook the reading of titles and abstracts and applied the STROBE checklist independently. The Odds Ratio was calculated using the random effects model. Eight studies were included in this meta-analysis and involved 21415 individuals. All the studies covered most of the items suggested by the STROBE checklist. Of the total, four studies showed association between sedentary behavior and nutritional status. Longer exposure to sedentary behavior did not increase the odds of overweight and/or obesity (OR 1.32; 95\%; Cl 0.95-1.84). It is suggested that further studies with standardized criteria for measuring sedentary behavior and nutritional status are undertaken. Level of Evidence ll; Systematic review of level Il studies.
\end{abstract}

Keywords: Sedentary lifestyle; Overweight; Malnutrition; Aged.

\section{RESUMO}

O acelerado processo de modernização tem acarretado mudanças no estilo de vida das pessoas, como a exposição ao comportamento sedentário, eesta, por sua vez, pode afetar o estado nutricional. Oobjetivo desta revisão sistemática com metanálisefoi analisar estudos observacionais, que avaliaram a associação entre tempo de exposição ao comportamento sedentário e estado nutricional (excesso de peso/desnutrição) em indivíduos com idade $\geq 60$ anos. BVS, PubMed e Web of Science foram as bases de dados utilizadas para a busca de estudos observacionais, publicados até 28 de novembro de 2017, que analisaram a associação entre tempo de exposição ao comportamento sedentário e estado nutricional. Dois autores realizaram a leitura de títulos e resumos e aplicaram o checklist STROBE de forma independente. Odds Ratio foi calculado utilizando o modelo de efeito aleatório. Foram incluídos nesta metanálise oito estudos, envolvendo 21415 indivíduos. Todos os estudos atenderam a maior parte dos itens sugeridos pelo checklist STROBE. Do total, quatro estudos apresentaram associação entre comportamento sedentário e estado nutricional. Maior tempo exposto ao comportamento sedentário não aumentou as chances de sobrepeso e/ou obesidade (OR 1,32; 95\%; IC 0,95-1,84). Sugere-se que novos estudos com critérios padronizados de mensuração de comportamento sedentário eestado nutricional sejam realizados. Nível de Evidência ll; Revisão sistemática de estudos de nível II.

Descritores: Estilo de vida sedentário; Sobrepeso; Desnutrição; Idoso.

\section{RESUMEN}

El proceso de modernización acelerado ha consistido en cambios en el estilo de vida de las personas, entre ellas la exposición a conductas sedentarias, y esto, a su vez, puede afectar el estado nutricional. El objetivo de esta revisión sistemática con meta-análisis fue analizar los estudios observacionales que evaluaron la asociación entre el tiempo de exposición a conductas sedentarias y estado nutricional (sobrepeso/desnutrición) en individuos de edad $\geq 60$ años. BVS, PubMed y Web of Science fueron las bases de datos utilizadas para la búsqueda de estudios observacionales, publicadas hasta el 28 de noviembre de 2017, que han examinado la asociación entre el tiempo de exposición a conductas sedentarias y el estado nutricional. Dos autores realizaron la lectura de los títulos, resúmenes y aplicación de la lista de verificación STROBE, independientemente. EI Odds Ratio se calculó utilizando el modelo de efectos aleatorios. Fueron incluidos en este meta-análisis ocho estudios, envolviendo 21415 individuos. Todos los estudios respondieron a la mayoría de los elementos sugeridos por la lista de verificación STROBE. Del total, cuatro estudios mostraron asociación entre conductas sedentarias y estado nutricional. Una mayor exposición a conductas sedentarias no ha aumentado las probabilidades de sobrepeso y obesidad (OR 1.32; 95\%; IC 0.95-1.84). Se sugiere que estudios adicionales con criterios de medición estandarizada de conductas sedentarias y estado nutricional se lleve a cabo. Nivel de Evidencia ll; Revisión sistemática de estudios de nivel Il.

Descriptores: Estilo de vida sedentario; Sobrepeso; Desnutrición; Anciano. 


\section{INTRODUCTION}

Due to the modernization process occurring in recent years, significant changes in people's lifestyle have been observed, such as altered eating habits, reduced physical activity ${ }^{1}$ and increased exposure time to sedentary behavior? ${ }^{2}$.

Sedentary behavior is an emerging problem and has been treated as a public health issue ${ }^{3}$. Increased exposure time to this behavior has been associated with several deleterious health factors, such as all-cause mortality ${ }^{4-6}$, depression ${ }^{7,8}$, diabetes type $2^{5,9,10}$, obesity ${ }^{11}$, metabolic syndrome ${ }^{5,12}$, cardiovascular diseases $5,9,13,14$ and certain types of cancer ${ }^{5}$.

In addition, diseases that accompany the aging process, such as changes in eating habits due to senescence, which may lead to excessive or insufficient food consumption in this population, can also contribute negatively to health in the elderly. One health indicator in particular, overweight, characterized by a body mass index (BMI) greater than or equal to $25 \mathrm{~kg} / \mathrm{m}^{2}{ }^{15}$, has increased in prevalence worldwide ${ }^{16}$.

Malnutrition, caused by constant inadequate consumption and deficient nutrient absorption, altered transport and use, leading to weight decreases and inflammatory processes common to this condition, is another deleterious elderly health problem ${ }^{17}$. However, little is known about the relationship between exposure time to sedentary behavior and nutritional status in the elderly.

In this context, the aim of the present study was to perform a systematic review through a meta-analysis of observational studies that evaluated associations between exposure time to sedentary behavior and nutritional status (overweight/malnutrition) of subjects aged $\geq 60$ years old.

\section{METHODS}

\section{Literature review}

A systematic review was carried out based on the search for observational studies published until $28^{\text {th }}$ July 2017, at the Virtual Health Library (VHL), National Library of Medicine (PubMed) and Web of Science databases.

The Boolean operators OR and AND were used in the search strategy, with OR used between synonyms of the applied search terms and AND when the objective was to associate two or more different search terms. The search was established through the use of descriptors (DeCS and MeSH terms), Boolean operators, filters and related terms.

The adopted search strategy was based on the combination of the following terms: "sedentary behavior" OR "sitting time" OR "sedentary lifestyle"OR "television viewing"OR "screen-time"OR "computer"OR "driving" AND"nutritional status"OR "nutrition status"OR "obesity"OR"overweight" OR "malnutrition" OR "undernutrition" AND "aged" OR "elderly" OR "older people", for the PubMed and Web of Science databases and "sedentary behavior" OR "sitting time" OR "sedentary lifestyle" OR "television" OR "driving vehicle" AND"nutritional status" OR"obesity"OR"overweight" OR "malnutrition" AND "aging" OR "elderly" for the VHL database.

\section{Study selection}

Two reviewers (BFC, TIMR) independently read the titles and abstracts of each selected article, and divergences were solved by consensus. In order to include relevant studies not identified in the database-indexed journals, a manual search was performed of the references cited by each article included in the review.

The adopted exclusion criteria were: a) articles written in a language other than Portuguese, English or Spanish; b) studies performed in individuals under the age of 60 ; c) meta-analysis, systematic reviews, narrative reviews, dissertations and theses. The obtained studies were imported to the EndNote Web reference management program (Thomson Reuters, Carlsbad, CA, USA) to exclude duplicate entries.

\section{Data extraction}

Aspects considered when analysing the selected articles were: author; year of publication; country; age; sample size; type of study (cohort, case-control or cross-sectional); objectives, instruments applied for the definition of sedentary behavior; BMI classification, adjustment variables, effect measures and the amount of items reported by the Strengthening the Reporting of Observational Studies in Epidemiology (STROBE) evaluation.

\section{Study analysis}

The selected articles were analyzed by means of the STROBE instrument, comprising 22 items that report aspects that should be included for an adequate description of observational studies.

\section{Statistical analyses}

All analyses were performed using the R software version 3.1.3. The Odds Ratio (OR) and 95\% confidence interval (Cl) parameters were adopted, significant at $p \leq 0.05$. The overall OR was considered in studies where the analysis was stratified separately for men and women.

The random effect model was considered for the meta-analysis of associations between greater exposure time to sedentary behavior and nutritional status ${ }^{18}$.

Heterogeneity was analyzed by means of the $\mathrm{I}^{2}$ statistic, taking into account the proportion of variation of the effect estimates, instead of considering sample error. For heterogeneity to be considered, $I^{2}$ should be higher than $75 \%{ }^{19}$.

\section{RESULTS}

Figure 1 displays the flowchart of the article selection process. Initially, 16395 articles were identified in the investigated databases. After applying the chosen filters (article category, comprising observational and human studies), 5303 articles displayed potential relevance. Of these, 141 were duplicates and, thus, excluded, with 5042 articles remining in English, 82 in Spanish and 38 in Portuguese. Of the remaining 5162 articles, 4740 were indexed in the Web of Science database, 391 in Pubmed and 31 in the VHL. After checking titles and abstracts, 51 articles were selected for full reading. Of this total, 38 were excluded with justifications and 13 met the inclusion criteria.

After performing a manual search of the references of the selected articles, 622 studies were identified and three were added to the analysis, totaling 16 articles. Of the remaining articles, eight were excluded because they did not present $O R$ values as an effect measure, with eight articles remaining in the meta-analysis.

The characteristics of each study are listed in Table 1. All eight articles included in the meta-analysis are cross-sectional studies. The study sample ranged from 124 to 14560 elderly people, totaling 21415 people involved in the study. Participant age ranged from 60 to 100 years old. Year of publication ranged from 2007 to 2014. Five studies were carried out in developed countries, (Canada, Spain and Japan ${ }^{20-24}$ ) and three in developing countries (Brazil, Puerto Rico and the Dominican Republic) ${ }^{25-27}$. All studies evaluated time of exposure to sedentary behavior through questionnaires, presenting different forms of sedentary behavior classification (tertiles, mean and medians).

The activities characterized as markers for sedentary behavior varied among the studies. Two studies evaluated sedentary behavior through total sitting time (hours/day) from the weighted average of sitting times on a week day and a weekend day ${ }^{25,26}$; two evaluated time spent watching TV, reported as hours/day ${ }^{27}$ and minutes/day ${ }^{22}$, from the median obtained from the last seven days of the week. 


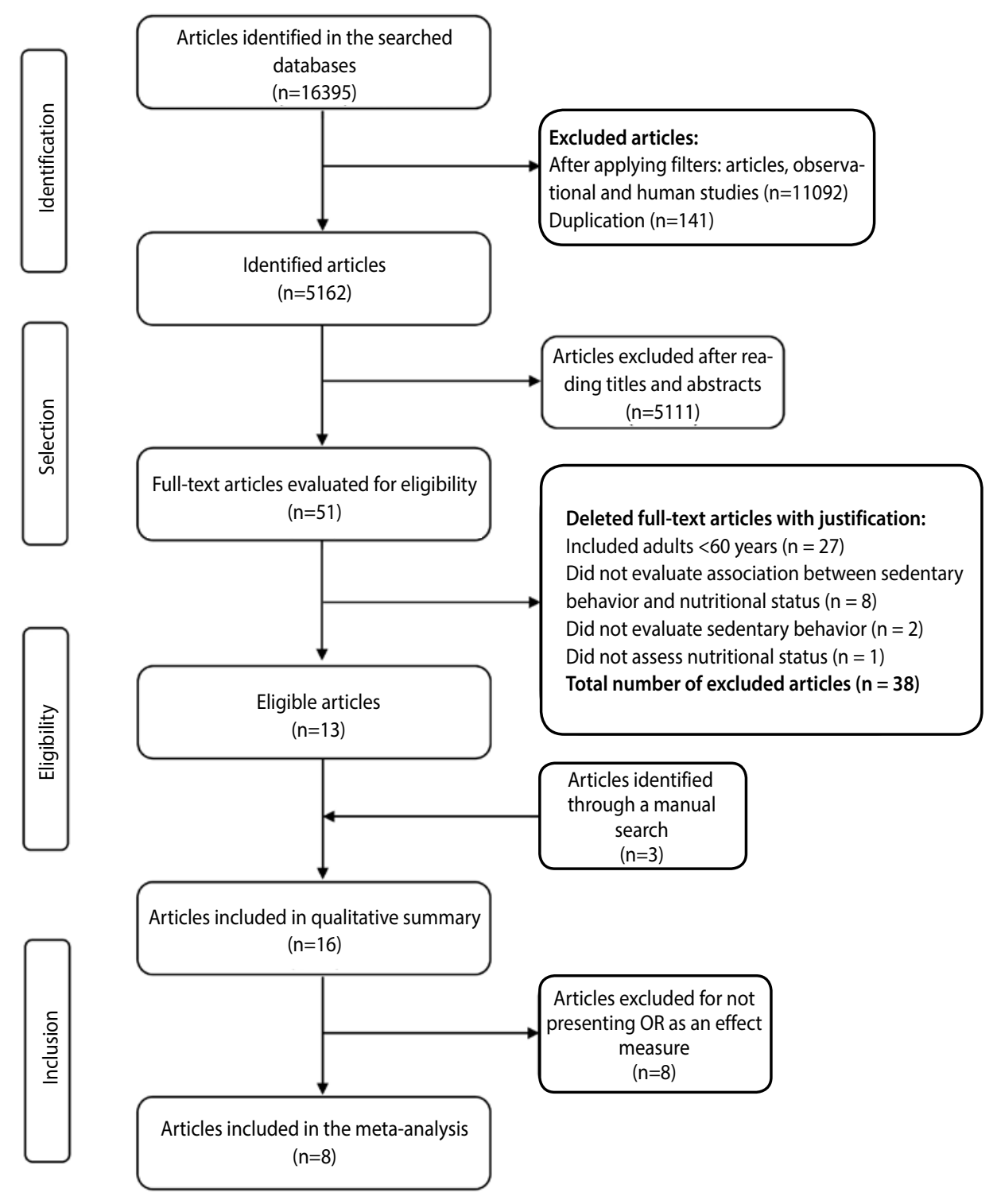

Figure 1. Flowchart of the identification of observational studies reporting association between sedentary behavior and nutritional status.

In one study, sedentary behavior was assessed by time spent watching TV or video (minutes/day) during the last seven days ${ }^{23}$. Similarly, another study carried out an analysis on sedentary behavior (minutes/ day) in the last seven days regarding leisure sedentary behavior (watching TV, using a computer, reading books and newspapers and listening or talking while sitting $)^{24}$. In two other studies, sedentary behavior was analyzed through sitting time (hours/day) $)^{20,21}$.

Regarding body mass index (BMI) classification, two studies used the criteria proposed by the Nutrition Screening Initiative ${ }^{28}$, that classifies an individual as overweight when presenting BMI> $27 \mathrm{~kg} / \mathrm{m}^{2} 25,26$. In one study, overweight individuals were classified when presenting $\mathrm{BMI} \geq 25 \mathrm{~kg} / \mathrm{m}^{2}$, but the reference for this choice was not reported ${ }^{23}$. Two other studies ${ }^{21,27}$ presented the cut-off point proposed by World Health Organization ${ }^{15}$. After contact with three authors who did not present the reference for the BMI cutoffs in their studies ${ }^{20,22,24}$, it was discovered that they also applied the model proposed by the World Health Organization, which classifies overweight individuals as BMI $\geq 25 \mathrm{~kg} / \mathrm{m}^{2}$, totaling five articles applying the same reference.
Seven studies $20,22-24,25-27$ presented a combined outcome of both men and women and one study evaluated only women ${ }^{21}$.

The number of items answered by the checklist varied between the STROBE-analyzed articles. Three studies $20,23,26$ complied with 18 STROBE items, another three $e^{21,25,27}$ with 19 items, and two ${ }^{22,24}$ with 20 of the 22 items suggested by the instrument.

The results of the association between greater exposure time to sedentary behavior and overweight are presented in Figure 2. An $I^{2}$ of $86 \%$ and $P_{\text {heterogeneity }}$ of 0.0001 were observed. Four studies showed an association between these variables $21,23,24,2$. However, greater exposure time to sedentary behavior did not increase the chance for individuals aged 60 or older being overweight/obesity (OR 1.32, 95\% Cl 0.95-1.84).

\section{DISCUSSION}

The systematic review conducted herein with a meta-analysis involving eight studies indicated that more time spent in sedentary behavior did not increase the chances of individuals being overweight/obesity. 
Table 1. Characteristics of the articles included in the meta-analysis.

\begin{tabular}{|c|c|c|c|c|c|c|c|c|c|c|}
\hline \multirow{2}{*}{$\begin{array}{l}\text { Auhor } \\
\text { and year }\end{array}$} & \multirow{2}{*}{ Country } & \multirow{2}{*}{ Age } & \multirow{2}{*}{ Sample } & \multirow{2}{*}{ Type of study } & \multirow{2}{*}{ Objective } & \multicolumn{2}{|c|}{ Sedentary behavior } & \multirow{2}{*}{$\begin{array}{c}\text { BMI } \\
\text { classification }\end{array}$} & \multirow{2}{*}{ Adjustment } & \multirow{2}{*}{ Strobe } \\
\hline & & & & & & $\begin{array}{l}\text { Evaluation } \\
\text { instrument }\end{array}$ & Definition & & & \\
\hline $\begin{array}{l}\text { Boscatto et } \\
\text { al. } 2013\end{array}$ & Brazil & $80-100$ & 124 & Cross-sectional & $\begin{array}{c}\text { Examine the association } \\
\text { between nutritional status } \\
\text { and sociodemographic } \\
\text { variables, health conditions } \\
\text { and lifestyle of both } \\
\text { men and women }\end{array}$ & Questionnaire & $\begin{array}{l}\text { Time sitting } \\
<4 \text { hours/day } \\
4-6 \text { hours/day } \\
\geq 6 \text { hours/day }\end{array}$ & $\begin{array}{c}\text { Nutrition } \\
\text { Screening } \\
\text { Initiative, } 1992\end{array}$ & $\begin{array}{l}\text { Sex, medication } \\
\text { use and smoking }\end{array}$ & 19 \\
\hline $\begin{array}{c}\text { Dogra e } \\
\text { Stathokostas } \\
2014\end{array}$ & Canada & $\geq 65$ & 14560 & Cross-sectional & \begin{tabular}{|c|} 
Identify potential \\
sociodemographic, \\
physical environmental, \\
psychosocial and health \\
variables correlated to \\
sitting time in the elderly \\
\end{tabular} & Questionnaire & $\begin{array}{l}\text { Time sitting } \\
<4 \text { hours/day } \\
\geq 4 \text { hours/day }\end{array}$ & WHO, 1995 & Age and sex & 18 \\
\hline $\begin{array}{l}\text { Fares } \\
\text { et al. } 2012\end{array}$ & Brazil & $60-100$ & 768 & Cross-sectional & $\begin{array}{l}\text { To verify the association } \\
\text { of nutritional status } \\
\text { with sociodemographic, } \\
\text { lifestyle and conditions } \\
\text { of both men and } \\
\text { women in two different } \\
\text { municipalities in Brazil }\end{array}$ & Questionnaire & $\begin{array}{l}\text { Time sitting } \\
<4 \text { hours/day } \\
4-6 \text { hours/day } \\
\geq 6 \text { hours/day }\end{array}$ & $\begin{array}{c}\text { Nutrition } \\
\text { Screening } \\
\text { Initiative, } 1992\end{array}$ & \begin{tabular}{|c|} 
Age, sex, family \\
arrangement, \\
smoking, \\
hypertension, \\
arthrosis, medications, \\
lifelong occupation, \\
and alcohol \\
consumption
\end{tabular} & 18 \\
\hline $\begin{array}{c}\text { Gao, Nelson } \\
\text { e Tucker } \\
2007\end{array}$ & \begin{tabular}{|c|} 
Porto \\
Rico and \\
Dominican \\
Republic
\end{tabular} & $\geq 60$ & 455 & Cross-sectional & $\begin{array}{l}\text { Examine the association } \\
\text { between TV viewing } \\
\text { time and prevalence of } \\
\text { metabolic syndrome }\end{array}$ & Questionnaire & $\begin{array}{c}\text { Watch TV } \\
\leq 840 \text { minutes/week } \\
>840 \text { minutes/week }\end{array}$ & WHO, 1995 & $\begin{array}{l}\text { Age, sex, ethnicity, } \\
\text { schooling, family } \\
\text { arrangement, } \\
\text { smoking, alcohol } \\
\text { consumption } \\
\end{array}$ & 19 \\
\hline $\begin{array}{l}\text { Gomez- } \\
\text { Cabello et } \\
\text { al. } 2012\end{array}$ & Spain & $\geq 65$ & 457 & Cross-sectional & $\begin{array}{l}\text { Establish the influence } \\
\text { of sitting time on } \\
\text { the composition of } \\
\text { women's bodies }\end{array}$ & Questionnaire & $\begin{array}{l}\text { Time sitting } \\
<4 \text { hours/day } \\
\geq 4 \text { hours/day }\end{array}$ & WHO, 1995 & $\begin{array}{c}\text { Active behavior } \\
\text { (hours spent walking) }\end{array}$ & 19 \\
\hline $\begin{array}{l}\text { Inoue } \\
\text { et al. } 2012\end{array}$ & Japan & $65-74$ & 1806 & Cross-sectional & $\begin{array}{l}\text { Examine the joint } \\
\text { association of viewing } \\
\text { time and overweight } \\
\text { and obesity MVPA in } \\
\text { men and women }\end{array}$ & Questionnaire & $\begin{array}{c}\text { Watch TV } \\
\leq 840 \text { minutes/week } \\
>840 \text { minutes/week }\end{array}$ & WHO, 1995 & \begin{tabular}{|} 
Age, gender, \\
schooling professional \\
situation, hometown, \\
smoking, alcohol \\
consumption, and \\
physical functionality \\
\end{tabular} & 20 \\
\hline $\begin{array}{l}\text { Kikuchi } \\
\text { et al. } 2013\end{array}$ & Japan & $65-74$ & 1665 & Cross-sectional & \begin{tabular}{|} 
To analyze the \\
association between \\
sociodemographic \\
attributes and time spent \\
watching TV time in \\
both men and women \\
\end{tabular} & Questionnaire & $\begin{aligned} & \text { Watch TV } \\
< & 2 \text { hours/day } \\
> & 2 \text { hours/day }\end{aligned}$ & \begin{tabular}{|c|} 
Underweight \\
$<20 \mathrm{~kg} / \mathrm{m}^{2}$ \\
Normal weight \\
$20-24.9 \mathrm{~kg} / \mathrm{m}^{2}$ \\
Overweight \\
$\geq 25 \mathrm{~kg} / \mathrm{m}^{2 *}$ \\
\end{tabular} & $\begin{array}{l}\text { MVPA, Health self- } \\
\text { perception and BMI }\end{array}$ & 18 \\
\hline $\begin{array}{c}\text { Kikuchi et al. } \\
2014\end{array}$ & Japan & $65-74$ & 1580 & Cross-sectional & $\begin{array}{l}\text { Identify SBL categories and } \\
\text { examine the association } \\
\text { between health and } \\
\text { well-being rates in } \\
\text { bothmen and women }\end{array}$ & Questionnaire & \begin{tabular}{|c|} 
SBL (watching TV, \\
using a computer, \\
reading books \\
and newspapers, \\
listening or speaking \\
while sitting) \\
(minutes / day) \\
\end{tabular} & WHO, 1995 & $\begin{array}{c}\text { Age, sex, MVPA, } \\
\text { schooling, } \\
\text { municipality, } \\
\text { professional situation } \\
\text { and life arrangement }\end{array}$ & 20 \\
\hline
\end{tabular}

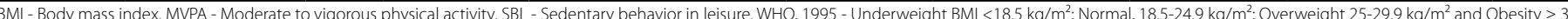
$\mathrm{kg} / \mathrm{m}^{2}$. Nutrition Screening Initiative, 1992 - Underweight BMI $<22.0 \mathrm{~kg} / \mathrm{m}^{2} ;$ Normal weight BMI $22.0-27.0 \mathrm{~kg} / \mathrm{m}^{2}$; Overweight $>27 \mathrm{~kg} / \mathrm{m}^{2}$. ${ }^{*}$ Reference not reported by the author.

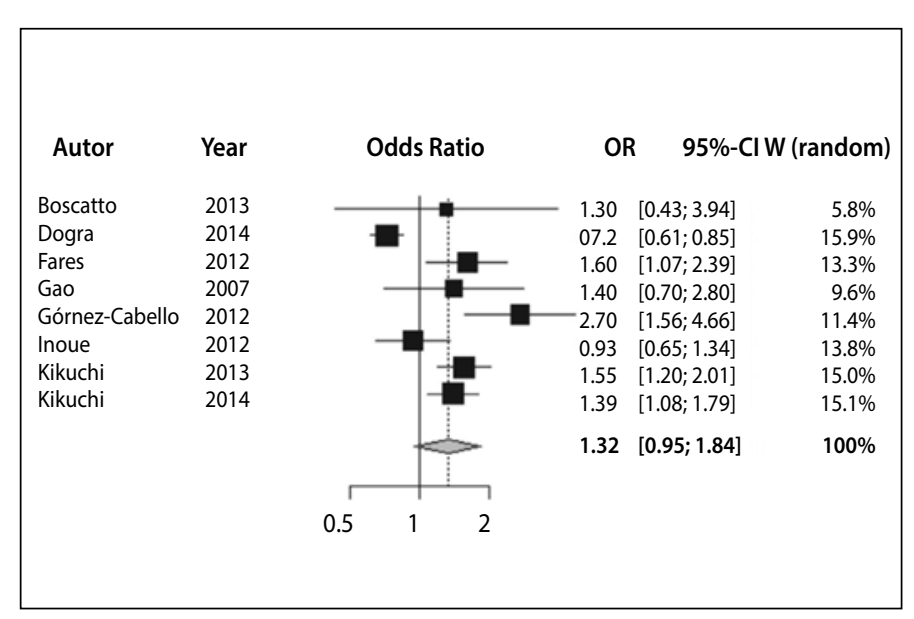

Figure 2. Forest plot of the association between sedentary behavior and overweight in the elderly.
The selected studies presented several divergences in certain parameters, such as age, sample size, adjustment variables, classification and cutoff points for sedentary behavior and BMI. Seven studies included both genders, while only one ${ }^{21}$ performed the analysis with women only.

Another noteworthy aspect is the lack of standardization regarding the instruments applied to measure exposure time to sedentary behavior. All studies included in the meta-analysis identified sedentary behavior through questionnaires (self-reported measure). However, other studies have measured sedentary behavior through accelerometers ${ }^{29-32}$.

The identification of sedentary behavior through self-reports has been widely applied in population studies, since this is a low-cost instrument with immediate applicability ${ }^{33-41}$. However, self-reports can underestimate the total sedentary time of individuals by omission or forgetfulness, the latter being common in the elderly population. Nevertheless, a good concurrent validity was verified when compared to a reference standard 
in a study with the aim of establishing the reproducibility and concurrent validity of a questionnaire measuring the level of physical activity and sedentary behavior in subjects aged $\geq 60^{42}$.

According to a literature survey, validated questionnaires applied in the measurement of sedentary behavior in the elderly are rare ${ }^{43,44}$ and, therefore, other instruments, such as the International Physical Activity Questionnaire (IPAQ), which deals with physical activity levels and includes specific questions related to total sitting time, have been applied ${ }^{42,45}$.

No consensus in the literature regarding the most applied marker to characterize time exposed to sedentary behavior exists. Of the studies included in this meta-analysis, four identified sedentary behavior through total sitting time $20,21,25,26$, three by time spent watching TV 22,23,27 and one by sedentary leisure behavior ${ }^{24}$. The variability in sedentary behavior markers and their respective cutoff points, in addition to the different characteristics of each study, may justify the high heterogeneity observed herein.

Although several studies use time spent watching TV as one of the main markers for sedentary behavior, a systematic review has demonstrated that this parameter should not be limited to this type of behavior ${ }^{46}$. The fact that some studies do not include other sedentary activities, such as those performed at work or at leisure, could underestimate total exposure time to sedentary behavior.

Some studies ${ }^{20-22,24,27}$ classified body mass index as proposed by the World Health Organization. Although this classification does not take into account the body changes that accompany the aging process, it has been one of the most applied references in epidemiological studies worldwide ${ }^{11,40,47,48}$.

None of the articles answered all twenty items evaluated by the STROBE instrument, which suggests the items necessary for a better description of observational studies, although most items suggested by this checklist were addressed. The analysis of studies through a checklist is increasingly recommended in systematic reviews and meta-analyses, since this instrument allows for the inclusion of studies that display greater clarity in data reporting.

No studies establishing an association between more time spent in sedentary behavior and malnutrition in the elderly were identified. Only two ${ }^{25,26}$ analyzed the relationship between sedentary behavior and underweight, but no significant results were found for this association. As the purpose of this meta-analysis is to identify the association between sedentary behavior and overweight/malnutrition and the term "low weight" is only indicative of a risk of malnutrition, these findings shall not be discussed.

Of the eight articles excluded from the meta-analysis because they did not present OR as a measure of effect or because they reported more than one OR, four reported no association between sedentary behavior and overweight ${ }^{31,32,36,49}$, three reported an association ${ }^{48,50,51}$ and one, which considered the results stratified by sex, reported a significant association only in women ${ }^{52}$. However, even if these studies were included in this meta-analysis, there would still be insufficient evidence of the relationship between longer exposure times to sedentary behavior and excess weight in the elderly.

This meta-analysis presents important highlights, including a large number of descriptors used in the search, no restriction regarding publication year, the analysis of both titles and abstracts, a checklist performed by two independent authors, a manual search through the references of each article included in the meta-analysis and a list of excluded articles with justifications.

Some limitations should also be noted, such as the fact that a high heterogeneity in the results was observed, due to sample variability, making it difficult to interpret the findings. All studies included in the meta-analysis were cross-sectional, which does not allow for the establishment of a causal relationship.

\section{CONCLUSIONS}

No significant associations were found between longer exposure to sedentary behavior and an overweight condition in subjects aged $\geq 60$ years old in this meta-analysis systematic review. Thus, the need to develop new studies with standardized criteria directed towards the evaluation of sedentary behavior and nutritional status in older individuals is pointed out.

\section{ACKNOWLEDGEMENTS}

We thank the Coordination of Improvement of Higher Education Personnel (CAPES) for its support in the form of study grants.

All authors declare no potential conflict of interest related to this article.

AUTHORS' CONTRIBUTIONS: Each author made significant individual contributions to this manuscript. BFC (0000-0002-3039-2194)*: writing, search strategy for databases, selection of articles, application of checklist, interpretation and discussion of results and review; TIMR (0000-0002-3058-4612)*: execution of the search in the databases, selection of articles, application of the checklist, discussion of results and critical review; EFAM (0000-0003-2659-5033)*: statistical analysis, assisted in the interpretation and discussion of the results and critical review; RD (0000-0001-5563-7349)*: study design, interpretation and discussion of results and critical review. All authors read and approved the final manuscript. *ORCID (Open Researcher and Contributor ID).

\section{REFERENCES}

1. Tardido AP, Falcão MC. O impacto da modernização na transição nutricional e obesidade. Rev Bras Nutr Clin. 2006;21(2):117-24.

2. Owen N, Sparling PB, Healy GN, Dunstan DW, Matthews CE. Sedentary behavior: emerging evidence for a new health risk. Mayo Clin Proc. 2010;85(12):1138-41.

3. Hallal PC, Andersen LB, Bull FC, Guthold R, HaskellW, Ekelund U. Global physical activity levels: surveillance progress, pitfalls, and prospects. Lancet. 2012;380(9838):247-57.

4. Lee I-M, Shiroma EJ, Lobelo F, Puska P, Blair SN, Katzmarzyk PT. Effect of physical inactivity on major non-communicable diseases worldwide: an analysis of burden of disease and life expectancy. Lancet. 2012;380(9838):219-29.

5. Rezende LFM, Lopes MR, Rey-López JP, Matsudo VKR, Luiz OC. Sedentary behavior and health outcomes: an overview of systematic reviews. PloS One. 2014;9(8):e105620.

6. Van der Ploeg HP, Chey T, Korda RJ, Banks E, Bauman A. Sitting time and all-cause mortality risk in 222497 Australian adults. Arch Intern Med. 2012;172(6): 494-500.

7. Pate RR, O'Neill JR, Lobelo F. The evolving definition of "sedentary". Exerc Sport Sci Rev. 2008;36(4):173-8.

8. Zhai L, Zhang Y, Zhang D. Sedentary behaviour and the risk of depression: a meta-analysis. Br J Sports Med. 2015;49(11):705-9.

9. Proper KI, Singh AS, Van Mechelen W, Chinapaw MJM. Sedentary behaviors and health outcomes among adults. Am J Prev Med. 2011;40(2):174-82.
10. Wilmot EG, Edwardson CL, Achana FA, Davies MJ, Gorely T, Gray $\sqcup$, et al. Sedentary time in adults and the association with diabetes, cardiovascular disease and death: systematic review and meta-analysis. Diabetologia. 2012;55(11):2895-905.

11. Shuval K, Leonard T, Murdoch J, Caughy MO, Khol HW, Skinner CS. Sedentary behaviors and obesity in a low-income, ethnic-minority population. J Phys Act Health. 2013;10(1):132-6.

12. Edwardson CL, Gorely T, Davies MJ, Gray LJ, Khunti K, Wilmot EG, et al. Association of sedentary behaviour with metabolic syndrome: a meta-analysis. PLoS ONE. 2012;7(4):e34916.

13. Ford ES, Caspersen CJ. Sedentary behaviour and cardiovascular disease: a review of prospective studies. Int J Epidemiol. 2012;41(5):1338-53.

14. Healy GN, Matthews CE, Dunstan DW, Winkler EAH, Owen N. Sedentary time and cardio-metabolic biomarkers in US adults: NHANES 2003-06. Eur Heart J. 2011;32(5):590-7.

15. World Health Organization. Physical status: the use and interpretation of anthropometric: report of a WHO Expert Committee. Geneva, 1995.

16. Suemoto CK, Lebrao ML, Duarte YA, Danaei G. Effects of body mass index, abdominal obesity, and type 2 diabetes on mortality in community-dwelling elderly in São Paulo, Brazil: analysis of prospective data from the SABE study. J Gerontol A Biol Sci Med Sci. 2015;70(4):503-10.

17. White JV, Guenter P, Jensen G, Malone A, Schofield M. Consensus statement of the academy of nutrition and dietetics/American society for parenteral and enteral nutrition: characteristics recommended 
for the identification and documentation of adult malnutrition (Undernutrition). J Acad Nutr Diet. 2012;112(5):730-8.

18. Higgins JPT, Thompson SG, Deeks JJ, Altman DG. Measuring inconsistency in meta-analyses. BMJ. 2003;327(7414):557-60.

19. Sterne JAC, Sutton AJ, Loannidis JPA, Terrin N, Jones DR, Lau J, et al. Recommendations for examining and interpreting funnel plot asymmetry in meta-analyses of randomised controlled trials. BMJ. 2011;343:d4002.

20. Dogra S, Stathokostas L. Correlates of extended sitting time in older adults: an exploratory crosssectional analysis of the Canadian Community Health Survey Healthy Aging Cycle. Int J Public Health. 2014;59(6):983-91.

21. Gomez-Cabello A, Vicente-Rodríguez G, Pindado M, Vila S, Casajús JA, Fuente FP, et al. Mayor riesgo de obesidad y obesidad central en mujeres post-menopáusicas sedentarias. Nutr Hosp. 2012;27(3):865-70.

22. Inoue S, Sugiyama T, Takamiya T, Oka K, Owen N, Shimomitsu T. Television viewing time is associated with overweight/obesity among older adults, independent of meeting physical activity and health guidelines. J Epidemiol. 2012;22(1):50-6.

23. Kikuchi H, Inoue S, Sugiyama T, Owen N, Oka K, Shimomitsu T. Correlates of prolonged television viewing time in older Japanese men and women. BMC Public Health. 2013;13:213.

24. Kikuchi H, Inoue S, Sugiyama T, Owen N, Oka K, Nakaya T, Shimomitsu T. Distinct associations of different sedentary behaviors with health-related attributes among older adults. Prev Med. 2014;67:335-9.

25. Boscatto EC, Duarte MFS, Coqueiro RS, Barbosa AR. Nutritional status in the oldest elderly and associated factors. Rev Assoc Med Bras (1992). 2013;59(1):40-7.

26. Fares D, Barbosa AR, Borgatto AF, Coqueiro RS, Fernandes MH. Fatores associados ao estado nutricional de idosos de duas regiões do Brasil. Rev Assoc Med Bras. 2012;58(4):434-41.

27. Gao X, Nelson ME, Tucker KL. Television viewing is associated with prevalence of metabolic syndrome in Hispanic elders. Diabetes Care. 2007;30(3):694-700.

28. Nutrition Screening Initiative. Incorporating nutrition screening and interventions into medical practice: a monograph for physicians. Washington DC, 1994

29. Van der Berg JD, Stehouwer CDA, Bosma H, Van der Velde JHPM, Willems PJB, Savelberg HHCM. Associations of total amount and patterns of sedentary behaviour with type 2 diabetes and the metabolic syndrome: the Maastricht study. Diabetologia. 2016;59(4):709-18.

30. Diaz KM, Howard VJ, Hutto B, Colabianchi N, Vena JE, Blair SN, et al. Patterns of sedentary behavior in US middle-age and older adults: the REGARDS study. Med Sci Sports Exerc. 2016;48(3):430-8.

31. Sartini C, Wannamethee SG, Iliffe S, Morris RW, Ash S, Lennon L, et al. Diurnal patterns of objectively measured physical activity and sedentary behaviour in older men. BMC Public Health. 2015;15(1):609.

32. Bann D, Hire D, Manini T, Cooper R, Botoseneanu A, McDermott MM, et al. Light intensity physical activity and sedentary behavior in relation to body mass index and grip strength in older adults: cross-sectional findings from the Lifestyle Interventions and Independence for Elders (LIFE) study. PLoS ONE. 2015;10(2): e0116058.

33. Al-Habsi A, Kilani H. Lifestyle of adults Omani Women: Cross-sectional study on physical activity and sedentary behaviour. Sultan Qaboos Univ Med J. 2015;15(2):e257-65.

34. Anderson S, Currie CL, Copeland JL. Sedentary behavior among adults: the role of community belonging. Prev Med Rep. 2016;4:238-41.

35. Bennie JA, Pedisic Z, Van Uffelen JGZ, Gale J, Banting LK, Vergeer I, et al. The descriptive epidemiology of total physical activity, muscle-strengthening exercises and sedentary behaviour among Australian adults - results from the National Nutrition and Physical Activity Survey. BMC Public Health. 2016;16:73.

36. Gianoudis J, Bailey CA, Daly RM. Associations between sedentary behaviour and body composition, muscle function and sarcopenia in community-dwelling older adults. Osteoporos Int. 2015;26 (2):571-9.

37. Jamil AT, Rosli NM, Ismail A, Idris IB, Omar A. Prevalence and risk factors for sedentary behavior among Malaysian adults. Malasian Journal of Public Health Medicine. 2016;16(3):147-55.

38. Ku PW, Fox KR, Chen LJ. Leisure-time physical activity, sedentary behaviors and subjective well-being in older adults: an eight-year longitudinal research. Soc Indic Res. 2016;127(3):1349-61.

39. Mitás J, Ding D, Frömel K, Keer J. Physical activity, sedentary behavior, and body mass index in the Czech Republic: a nationally representative survey. J Phys Act Health. 2014;11(5):903-7.

40. Meneguci J, Sasaki JE, Santos ÁS, Scatena LM, Damião R. Socio-demographic, clinical and health behavior correlates of sitting time in older adults. BMC Public Health. 2015;15(1):65.

41. Loprinzi PD, Sng E. The association of changes in sedentary behavior on changes in depression symptomology: pilot study. J Behav Health. 2016;5(3):140-4.

42. Benedetti TRB, Antunes PC, Rodriguez-Añez CR, Mazo GP, Petroski EL. Reprodutibilidade e validade do Questionário Internacional de Atividade Física (IPAQ) em homens idosos. Rev Bras Med Esporte. 2007;13(1):11-6.

43. Gardiner PA, Healy GN, Eakin EG, Clark BK, Dunstan DW, Shaw JE, et al. Associations between television viewing time and overall sitting time with the metabolic syndrome in older men and women: the Australian diabetes obesity and lifestyle study. J Am Geriatr Soc. 2011;59(5):788-96.

44. Visser M, Koster A. Development of a questionnaire to assess sedentary time in older persons-a comparative study using accelerometry. BMC Geriatr. 2013;13(1):80.

45. Benedetti TB, Mazo GZ, Barros MVG. Aplicação do Questionário Internacional de Atividades Físicas para avaliação do nível de atividades físicas de mulheres idosas: validade concorrente e reprodutibilidade teste-reteste. Rev Bras Ciênc Mov. 2004;12(1):25-34.

46. Clark BK, Sugiyama T, Healy GN, Salmon J, Dunstan DW, Owen N. Validity and reliability of measures of television viewing time and other non-occupational sedentary behaviour of adults: a review. Obes Rev. 2009;10(1):7-16.

47. Silva RC, Meneguci J, Martins TI, Santos ÁS, Sasaki JE, Tribess S, et al. Associação entre tempo sentado e diabetes mellitus em idosos: um estudo de base populacional. Rev Bras Cineantropom Desempenho Hum. 2015;17(4):379-88.

48. Marcellini F, Giuli C, Papa R, Gagliardi C, Malavolta M, Mocchegiani E. BMI, life-style and psychological conditions in a sample of elderly Italian men and women. J Nutr Health Aging. 2010;14(7):515-22.

49. Stamatakis E, Davis M, Stathi A, Hamer M. Associations between multiple indicators of objectively-measured and self-reported sedentary behaviour and cardiometabolic risk in older adults. Prev Med. 2012;54(1):82-7.

50. Gennuso KP, Gangnon RE, Matthews CE, Thraen-Borowski KM, Colbert LH. Sedentary behavior, physical activity, and markers of health in older adults. Med Sci Sports Exerc. 2013;45(8):1493-500

51. Intorre F, Maiani G, Cuzzolaro M, Simpson EEA, Catasta G, Ciarapica D, et al. Descriptive data on lifestyle, anthropometric status and mental health in italian elderly people. J Nutr Health Aging. 2007;11 (2):165-74

52. Gomez-Cabello A, Pedrero-Chamizo R, Olivares PR, Hernández-Perera R, Rodríguez-Marroyo JA, Mata

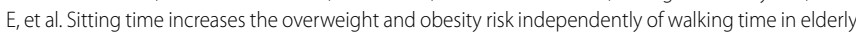
people from Spain. Maturitas. 2012;73(4):337-43. 